\title{
The Chronically Reserpinized Rat as a Model for Cystic Fibrosis: Alterations in the Mucus- Secreting Sublingual Gland
}

\author{
J. RICARDO MARTINEZ, ${ }^{(39)}$ DAVID B. BYLUND, THOMAS MAWHINNEY, JEAN CAMDEN, AND \\ GENE RAY \\ Departments of Child Health, Pharmacology and Physiology, University of Missouri School of Medicine, Columbia, \\ Missouri, USA
}

\begin{abstract}
Summary
The chronic administration of reserpine $(0.5 \mathrm{mg} / \mathrm{kg}$ body weight, daily for 7 days) increases the density of adrenergic receptors in the sublingual gland of the rat. The $B_{\max }$ values (in pmole/g tissue) were $5.8 \pm 0.9$ for $\left[{ }^{3} \mathrm{H}\right]$-prazosin, $22 \pm 4$ for $\left[{ }^{3} \mathrm{H}\right]$-clonidine and $11.9 \pm 1.7$ for $\left[{ }^{3} \mathrm{H}\right]$-dihydroalpranolol. These radioligands are used, respectively, for the study of $\alpha_{1}, \alpha_{2}$ and $\beta$-adrenergic receptors and the $B_{\max }$ values indicated are 181,226 , and $331 \%$, respectively, of the corresponding values in control sublingual glands. The increase in the density of $\alpha_{1}$-adrenregic receptors was accompanied by the development of a clear secretory response to norepinephrine and phenylephrine, as judged by the ability to release $\mathrm{K}^{+}$ in vitro. This response, which was not observed in control sublingual glands, amounted to $21.9 \pm 2.5$ and $16.8 \pm 3.1 \%$ of the tissue content of $\mathrm{K}^{+}$, respectively, for the two agonists. Neither the density of muscarinic cholinergic receptors $\left(B_{\max }=106 \%\right.$ of control value) nor the extent of $\mathrm{K}^{+}$release elicited by carbamylcholine was modified by the drug treatment, when compared to those observed in control glands. In vivo, the volume of sublingual saliva secreted in response to i.v. infusions of acetylcholine was significantly reduced in the treated animals to $45 \%$ of that secreted by control rats. This was accompanied by increases in salivary concentrations of protein-bound carbohydrates, with no change in the individual carbohydrate ratios. No significant changes in salivary electrolyte concentrations $\left(\mathrm{Na}^{+}, \mathrm{K}^{+}, \mathrm{Ca}^{++}\right)$were observed in sublingual saliva of reserpine-treated rats. In summary, reserpine administration alters adrenergic receptor density and sensitivity in the rat sublingual gland and modifies its secretory responses both in vitro and in vivo. The chronic administration of reserpine to rats causes widespread exocrine gland disturbances resembling those of cystic fibrosis. The results of this study show that the drug treatment also affects a mucus-secreting salivary gland and support the view that the reserpine-treated rat is a useful experimental model of the human disease.
\end{abstract}

\section{Abbreviations}

CF, cystic fibrosis

DHA, dehydroalprenolol

QNB, quinuclidinyl benzylate

Previous evidence from this laboratory has demonstrated that the chronic administration of reserpine to rats causes widespread exocrine gland abnormalities, which resemble those observed in patients with cystic fibrosis $(13,14,15,24,26,27,31,32,33)$. Morphologic and functional disturbances have been documented in both serous (parotid gland, pancreas) and seromucous (submandibular) glands of the rat. More recently, we have reported alternations in glycoprotein content of pulmonary lavage samples $(18,19)$ and in the secretion of prelabeled glycoproteins from an isolated, perfused tracheal preparation from reserpine-treated rats (20). Forstner et al. (9) have also shown that intestinal goblet cells of reserpine-treated rats contain 1.4 times more mucin than control tissue and that in vitro secretion of mucin was 3 times greater in the treated animals.

These observations suggest that the drug treatment also affects mucus-secreting exocrine tissues. The rat sublingual gland is composed of mucous acini surrounded by serous demilunes and myoepithelial cells $(10,30,34)$. Sublingual saliva is a mucin-rich secretion containing moderate amounts of carbohydrate-rich glycoproteins $(10,25)$. Because alterations in mucus-secreting exocrine glands seem to be a primary disturbance in cystic fibrosis, it became of interest to assess the effects of chronic reserpine administration on a mucous salivary gland of the experimental animal model. The possibility that drug treatment may induce pronounced alterations in the rat sublingual gland was strengthened by the previously mentioned observations on airways and intestine. Results of drug treatment would provide additional evidence of the widespread nature of the exocrinopathy in the animal model and allow a comparison to be made of drug-induced alterations between mucous and non-mucous exocrine glands. In this study we have, therefore, assessed the effects of chronic reserpine administration on the secretory capacity of the rat sublingual gland, both in vitro and in vivo. Inasmuch as previous observations have shown that the drug treatment alters the density of adrenergic receptors in the submandibular gland $(3,4,5,6)$, studies were performed to determine drug effects on autonomic receptors in the mucus-secreting sublingual gland.

\section{MATERIALS AND METHODS}

Sprague-Dawley rats weighing $175-250 \mathrm{~g}$ had free access to water and to a standard pellet diet. Some animals in each group received seven daily injections of reserpine $(0.5 \mathrm{mg} / \mathrm{kg}$ body weight, i.p.), as previously described $(13,14,15)$. The animals were anesthetized with sodium pentobarbital $(5-8 \mathrm{mg} / 100 \mathrm{~g}$ body weight) and the sublingual glands were removed and processed either for the receptor assay by radioligand binding or for the measurement of $\mathrm{K}^{+}$in vitro.

In the first case, glands from control and reserpinized animals were separately homogenized twice with a Tissumizer homogenizer in 20 volumes of ice cold $50 \mathrm{mM}$ Tris $\left(\mathrm{pH} 8.0\right.$ at $\left.25^{\circ} \mathrm{C}\right)$ and centrifuged at $49,000 \times g$ for $10 \mathrm{~min}$. The crude particulate fraction pellet was resuspended in 100-150 volumes of buffer. For the binding assay, $970 \mu \mathrm{l}$ of this suspension were incubated for $30-40 \mathrm{~min}$ at $23^{\circ} \mathrm{C}$ with various concentrations of a $\left[{ }^{3} \mathrm{H}\right]$-ligand (6). The suspensions were filtered through $G B / B$ glass-fiber Whatman filters, washed with buffer and the radioactivity remaining on the filter was determined by scintillation spectroscopy at an efficiency of $38 \%$. Nonspecific binding, measured in parallel incubation tubes containing the appropriate concentration of unla- 
beled drug was subtracted from the total binding to obtain the specific binding. The final concentrations of labeled and unlabeled

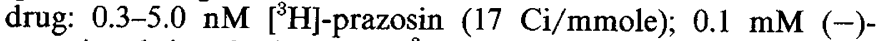
norepinephrine; $0.26-4.0 \mathrm{nM}\left[{ }^{3} \mathrm{H}\right]$-quinuclidinyl benzylate (QNB, $40 \mathrm{Ci} / \mathrm{mmole}) ; 1 \mu \mathrm{M}$ atropine; $0.1-3.0\left[{ }^{3} \mathrm{H}\right]-\mathrm{DHA}, 50 \mathrm{Ci} / \mathrm{mmole}$ ); $0.3 \mu \mathrm{M}$ (-)-propranolol; $0.2-6.0\left[{ }^{3} \mathrm{H}\right]$-clonidine $(24 \mathrm{Ci} / \mathrm{mmole}) ; 1$ $\mu \mathrm{M}(-)$-norepinephrine. Both the density of receptors $\left(\mathrm{B}_{\max }\right)$ and their affinity $\left(K_{D}\right)$ were determined from saturation experiments with five concentrations of the radioligand. The data were plotted as bound/free versus bound (29) and calculated by an unweighted linear regression analysis: The $\mathrm{B}_{\max }$ values for control glands were taken from Martinez et al. (17). These values were obtained in untreated rats in parallel experiments to the ones reported here.

For the measurement of $\mathrm{K}^{+}$release, the excised glands from control and treated rats were immediately placed in a beaker containing $5-10 \mathrm{ml}$ of oxygenated Krebs-Ringer bicarbonate medium (16) warmed to $37^{\circ} \mathrm{C}$. The glands were rapidly cut with a sharp scalpel blade into sections of approximately $1 \mathrm{~mm}^{3}$. Slices from several glands were mixed and divided into 3-5 equal portions. Each portion was then placed in a nitrocellulose tube containing $1 \mathrm{ml}$ of fresh medium and preincubated for $10 \mathrm{~min}$. The slice systems were then washed and placed in $1 \mathrm{ml}$ of fresh, final incubation medium. Drugs were added to this medium at zero time and, subsequently, aliquots of the medium were removed at timed intervals, usually 2,5 , and $10 \mathrm{~min}$. The basal release of $\mathrm{K}^{+}$was measured in the absence of added drug. At the end of the incubation period, the slices were homogenized in the remaining medium with a Polytron homogenizer. The $\mathrm{K}^{+}$content of the aliquots removed in the course of the experiment and in the slice homogenate was measured in an Instrumentation Laboratories flame photometer with lithium internal standard. The release of $\mathrm{K}^{+}$was calculated as a $\%$ of the $\mathrm{K}^{+}$content of the tissue, using the formula previously described (16). In some experiments, the composition of the incubation medium was altered, either by the removal of $\mathrm{K}^{+}$or $\mathrm{Ca}^{++}$or by the addition of $10^{-3} \mathrm{M}$ ouabain (see "Results").

In vivo secretory responses were assesed by collecting and analyzing saliva samples from anesthetized animals. Control and reserpine-treated rats were anesthetized with i.p. injections of sodium pentobarbital (6-8 mg/100 $\mathrm{g}$ body weight) and the submandibular-sublingual gland complex was dissected on both sides. The main excretory duct of each sublingual was identified and cannulated with a short length of polyethelene tubing (Clay Adams PE10), pulled at the tip over a microflame to a diameter of 15-25 $\mu$. The external jugular vein was also identified and cannulated with a plastic tube (Clay Adams PE50) connected to a constant infusion pump. Stimulation of saliva secretion was accomplished by the i.v. infusion of acetylcholine chloride. A solution containing $400 \mu \mathrm{g} / \mathrm{ml}$ was infused at a rate of $0.052 \mathrm{ml}$ / min. Saliva samples were collected at timed intervals in preweighed plastic microsample tubes and the volume of saliva in each was estimated by reweighing the collection tubes. Samples were analyzed for $\mathrm{Na}^{+}$and $\mathrm{K}^{+}$using an Instrumentation Laboratories flame photometer with lithium internal standard, for $\mathrm{Ca}^{++}$ using the Corning Instruments calcium analyzer and for protein by the Lowry method. Carbohydrate content was measured by dissolving saliva in $1.0 \mathrm{ml}$ of $5.0 \mathrm{M}$ guanidinium hydrochloride in $0.05 \mathrm{M}$ potassium phosphate buffer, $\mathrm{pH}$ 7.2. Samples were then exhaustively dialyzed against the above phosphate buffer without the chaotropic reagent in Spectra/Por 3 dialysis tubing (molecular weight exclusion limit $=3500$ ) to remove all free carbohydrates. Aliquots were then taken from each dialyzate and hydrolyzed under nitrogen in $0.6 \mathrm{~N} \mathrm{HCl}$ at $100^{\circ} \mathrm{C}$ for $4 \mathrm{hr}$ and $6.0 \mathrm{~N} \mathrm{HCl}$ for $8 \mathrm{~h}$ for neutral and amino sugars, respectively, and both analyzed by gas-liquid chromatography $(21,22)$. Sialic acid was liberated by hydrolysis in $1.0 \mathrm{ml}$ of $0.05 \mathrm{~N} \mathrm{H}_{2} \mathrm{SO}_{4}$ at $90^{\circ} \mathrm{C}$ for $1 \mathrm{~h} \mathrm{(36)}$ and then separated on a Dowex-2, 200-400 mesh, anion exchange resin (formate form) and eluted with $0.5 \mathrm{~N}$ formic acid (38). Formic acid was then removed in vacuo and the sialic acids were derivatized to their acyclic methyl ester ketoxime- $O$-trimethylsilyl derivatives and analyzed by gas-liquid chromatography (23).

All radioactively labeled drugs were purchased from New England Nuclear (Boston, MA). Carbamylcholine chloride, acetylcholine chloride, norepinephrine bitartrate, phenylephrine hydrochloride, isoproterenol hydrochloride and atropine sulfate were purchased from Sigma Chemical Company (St. Louis, MO). Clonidine hydrochloride was kindly donated by Boehringer Ingelheim, Elmsford, NY. Reserpine was purchased from Ciba Pharmaceutical Company (Serpasil, $2.5 \mathrm{mg} / \mathrm{ml}$ ). Dosages for the drugs used in these experiments are indicated in the "Results" section.

\section{RESULTS}

Autonomic receptors. Table 1 shows the results of the binding assays of specific radioligands for the cholinergic and adrenergic receptors. Both the affinity of the receptor for the specific ligand $\left(K_{D}\right)$ and the density of receptors $\left(B_{\max }\right)$ are shown in this table. The latter is expressed as $B_{\max }$ in pmole/g tissue, pmole/g protein and pmole/gland.

The sublingual gland from reserpine-treated animals had a moderate density of muscarinic cholinergic and $\alpha_{2}$-adrenergic receptors on the basis of the $B_{\max }$ for $\left[{ }^{3} \mathrm{H}\right]$-QNB and $\left[{ }^{3} \mathrm{H}\right]$-clonidine binding, respectively. The $B_{\max }$ for $\left[{ }^{3} \mathrm{H}\right]-\mathrm{QNB}$ was $106 \%$ of that observed in control glands whereas the $\mathrm{B}_{\max }$ for clonidine was $226 \%$ of the corresponding control value (pmole/g tissue). The density of both $\alpha_{1^{-}}$and $\beta$-adrenergic receptors increased after chronic reserpine administration. The $B_{\max }$ (pmole/g tissue) for $\left[{ }^{3} \mathrm{H}\right]$-prazosin labeling of $\alpha_{1}$-receptors was $5.8 \pm 0.9$. This is $181 \%$ of the corresponding value in control tissue. The $B_{\max }$ (pmole/g tissue) for $\left[{ }^{3} \mathrm{H}\right]-\mathrm{DHA}$ binding to $\beta$-receptors was $11.9 \pm 1.7$, which corresponds to $331 \%$ of the value obtained in control tissue. The $\mathrm{K}_{\mathrm{D}}$ values for glands from reserpinized animals (Table 1 ) were not significantly different $(P>0.05)$ to the $\mathrm{K}_{\mathrm{D}}$ values for control glands (17), except for the muscarinic cholinergic receptor, where the $\mathrm{K}_{\mathrm{D}}$ values for reserpinized glands were significantly greater $(P<0.01)$ than control glands.

$\mathrm{K}^{+}$release in vitro. As in the case of the control sublingual glands (17), the glands from reserpine-treated animals were found to release $\mathrm{K}^{+}$in a time-dependent fashion upon the addition of 2 $\times 10^{-5} \mathrm{M}$ carbamylcholine. The amount of $\mathrm{K}^{+}$released after 10 min of incubation was $38.4 \pm 4.2 \%$, a value which is not significantly different from the corresponding value in control slices $(35.1 \pm 7.0 \%)$ (Table 2$)$. The slices from the treated animals also released $\mathrm{K}^{+}$in the absence of stimulant (basal release) (Fig. 1). This release amounted to $11.3 \pm 2.6 \%$, which is not significantly different from the corresponding basal release observed in control slices $(9 \pm 1.4 \%)$. In contrast to control slices, the slices from the treated animals showed a significant release of $\mathrm{K}^{+}$in the presence

Table 1. Autonomic receptors in the sublingual gland ${ }^{1}$

\begin{tabular}{|c|c|c|c|c|c|c|c|c|c|}
\hline \multirow[b]{2}{*}{ Radioligand } & \multirow{2}{*}{$\begin{array}{c}\mathrm{K}_{\mathrm{D}} \\
(\mathrm{nM})\end{array}$} & \multirow[b]{2}{*}{$\%$ of $\mathrm{C}$} & \multicolumn{7}{|c|}{$\mathrm{B}_{\max }$ pmole } \\
\hline & & & per g Tissue & $\%$ of $\mathrm{C}$ & per g Protein & $\%$ of $\mathrm{C}$ & per Gland & $\%$ of $\mathrm{C}$ & $n$ \\
\hline [ $\left.{ }^{3} \mathrm{H}\right]-$ Prazosin & $0.29 \pm 0.09$ & 67 & $5.8 \pm 0.9$ & 181 & $105 \pm 22$ & 184 & $0.21 \pm 0.04$ & 175 & 4 \\
\hline$\left[{ }^{3} \mathrm{H}\right]-\mathrm{QNB}$ & $0.38 \pm 0.03$ & 181 & $19.5 \pm 1.4$ & 106 & $449 \pm 27$ & 94 & $0.70 \pm 0.06$ & 145 & 5 \\
\hline$\left[{ }^{3} \mathrm{H}\right]-$ DHA & $0.62 \pm 0.03$ & 124 & $11.9 \pm 1.7$ & 331 & $233 \pm 59$ & 333 & $0.36 \pm 0.10$ & 240 & 4 \\
\hline$\left[{ }^{3} \mathrm{H}\right]$-Clonidine & $2.10 \pm 0.17$ & 101 & $22 \pm 4$ & 226 & $370 \pm 70$ & 128 & $0.51 \pm 0.10$ & 176 & 4 \\
\hline
\end{tabular}

${ }^{1}$ The $B_{\max }$ (density of receptor binding sites) and $K_{D}$ (affinity) were determined for each radioligand in a crude particulate fraction of sublingual glands in saturation experiments. Values are means \pm S.E. $\left[{ }^{3} \mathrm{H}\right]-\mathrm{QNB}$, tritiated quinuclidinyl benzylate and $\left[{ }^{3} \mathrm{H}\right]-\mathrm{DHA}$, tritiated dihydroalprenolol. 
Table 2. Net $K^{+}$release from sublingual slices ${ }^{1}$

\begin{tabular}{lrrrr} 
& & \multicolumn{3}{c}{$\begin{array}{c}\text { Net } \mathrm{K}^{+} \text {release }(\%) \text { in } 10 \\
\text { min }\end{array}$} \\
\cline { 3 - 5 } \multicolumn{1}{c}{ Secretagogue } & & \multicolumn{1}{c}{ Control } & Reserpine \\
\hline None & & \multicolumn{1}{c}{$n$} \\
Carbamylcholine & $2 \times 10^{-5}$ & 4 & $35.1 \pm 7.0$ & $38.4 \pm 4.2$ \\
Norepinephrine & $2 \times 10^{-5}$ & 4 & $3.6 \pm 1.5$ & $21.9 \pm 2.5$ \\
Phenylephrine & $2 \times 10^{-5}$ & 3 & $-3.3 \pm 3.3$ & $16.8 \pm 3.1$ \\
Clonidine & $10^{-5}$ & 5 & $-0.1 \pm 3.7$ & $13.8 \pm 1.2$ \\
Isoproterenol & $10^{-5}$ & 3 & $4.1 \pm 1.4$ & $2.8 \pm 2.8$ \\
\hline
\end{tabular}

${ }^{1}$ Values are the mean net release of $\mathrm{K}^{+}( \pm$S.D.) observed after $10 \mathrm{~min}$ of incubation in the presence of the substances listed in the left column.

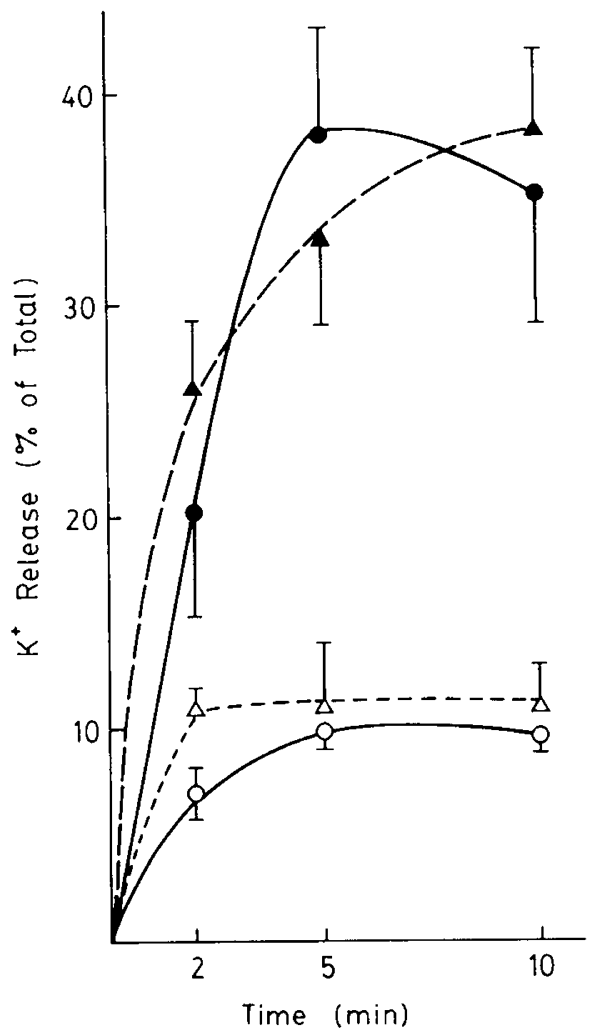

Fig. 1. Net $\mathrm{K}^{+}$release from sublingual gland slices of control (solid lines) and reserpine-treated rats (broken lines) in the absence (open symbols) and in the presence (closed symbols) of $2 \times 10^{-5} \mathrm{M}$ carbamylcholine. Vertical bars represent \pm S.E. Data is based on 4-6 experiments.

of norepinephrine and phenylephrine (Fig. 2 and Table 2); thus, $\mathrm{K}^{+}$release after 10 min of incubation in the presence of norepinephrine and phenylephrine was $21.9 \pm 2.5 \%$ and $16.8 \pm 3.1 \%$, respectively. These two adrenergic drugs were found to reduce net $\mathrm{K}^{+}$release below the basal release value in control sublingual slices (Table 2). Clonidine, which inhibited $\mathrm{K}^{+}$release from sublingual slices of control animals (see reference 17 and Table 2 ), caused $\mathrm{K}^{+}$release in slices of reserpine-treated rats to the extent of $13.8 \%$ (Fig. 2 and Table 2), but this value was not significantly different from that of the basal (unstimulated) $\mathrm{K}^{+}$ release $(11.3 \%$, Table 2$)$ observed in the same slices, which indicates that this drug does not enhance $\mathrm{K}^{+}$release above basal level in the slices of the treated animals. Clonidine has been reported to be an antagonist of $\mathrm{K}^{+}$release in salivary glands (7). Isoproterenol failed to induce $\mathrm{K}^{+}$release in the slices of the treated animals and in fact inhibited the basal release of $\mathrm{K}^{+}$(Table 2).

Previous evidence in both parotid (1) and submandibular gland (16) slice preparations has shown that the net release of $\mathrm{K}^{+}$in vitro is the result of two opposing and almost simultaneous mechanisms, a passive efflux which occurs as a result of an increased membrane permeability induced by receptor stimulation and an active $\mathbf{K}^{+}$ re-uptake, which depends on the activation of an ouabain-sensitive $\mathrm{Na}^{+}, \mathrm{K}^{+}$ATPase. Each component can be studied independently by appropriate manipulation of the experimental conditions. The extent of the passive efflux can be measured when the active uptake component is eliminated by inhibiting the $\mathrm{Na}^{+}, \mathrm{K}^{+}$ATPase with cardiac glycosides. The active uptake component can be measured by several methods, including the blockade of the previously stimulated receptor with an appropriate antagonist, or by pre-incubating the slices in $\mathrm{K}^{+}$-free medium and then transferring them to $\mathrm{K}^{+}$-containing medium. The two mechanisms have been shown to occur in the sublingual gland slice system of control rats (17). They were investigated in sublingual slices of reserpinetreated rats (this study) because prevous evidence has shown that, in the submandibular gland, active $\mathrm{K}^{+}$uptake is decreased after reserpine administration (16).

The passive efflux of $\mathrm{K}^{+}$from the slices of the treated animals was measured in the presence of $10^{-3} \mathrm{M}$ ouabain and, as shown in Table 3 , reached $35.3 \pm 3.2 \%$. This is essentially similar to that seen in control slices in the presence of the glycoside $(31 \pm 1.9 \%)$. As in control tissue, the passive efflux of $\mathrm{K}^{+}$was enhanced when carbamylcholine was added to the systems (to $79 \pm 12 \%$, Table 3 ). In control slices, norepinephrine did not increase the passive efflux of $\mathrm{K}^{+}$observed in the presence of ouabain (Table 3 ). In the slices

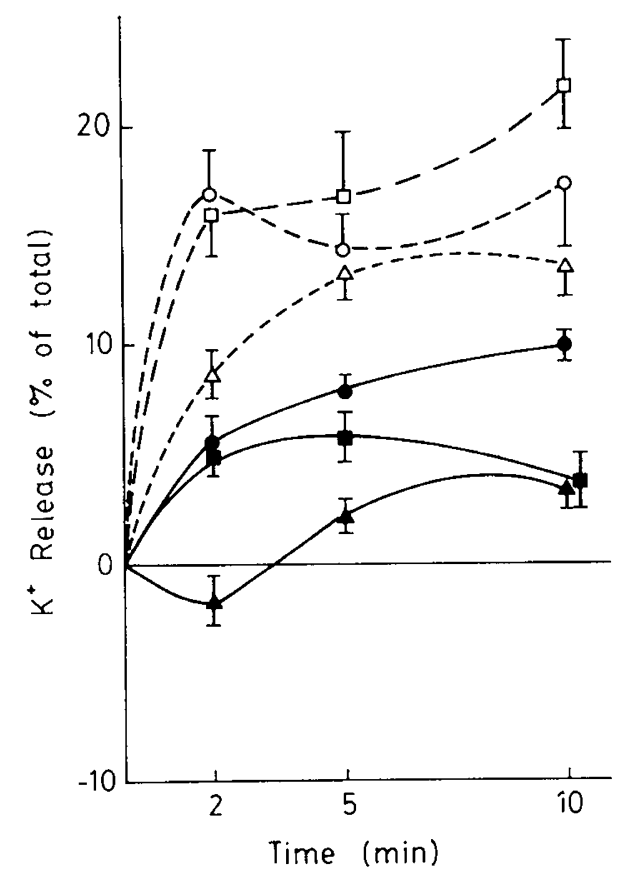

Fig. 2. Net $\mathrm{K}^{+}$release from sublingual slices of control (solid lines) and reserpine-treated rats (broken lines) in the presence of $2 \times 10^{-5} \mathrm{M}$ norepinephrine (squares), $2 \times 10^{-5} \mathrm{M}$ phenylephrine (circles) and $10^{-5} \mathrm{M}$ clonidine (triangles). Vertical bars represent \pm S.E. Number of experiments $=3-4$.

Table 3. Effect of ouabain on $K^{+}$release from the sublingual gland $^{1}$

\begin{tabular}{|c|c|c|c|c|}
\hline \multirow[b]{2}{*}{ Secretagogue } & \multirow{2}{*}{$\begin{array}{l}\text { Dose } \\
(\mathrm{M})\end{array}$} & \multirow[b]{2}{*}{$n$} & \multicolumn{2}{|c|}{$\mathrm{K}^{+}$release $(\%)$ in $10 \mathrm{~min}$} \\
\hline & & & Control & Reserpine \\
\hline Ouabain & $10^{-3}$ & 5 & $31.1 \pm 1.9$ & $35.3 \pm 3.2$ \\
\hline $\begin{array}{l}\text { Carbamylcholine }+ \\
\text { Ouabain }\end{array}$ & $\begin{array}{c}2 \times 10^{-5} \\
10^{-3}\end{array}$ & 4 & $84.2 \pm 14.6$ & $79.4 \pm 11.9$ \\
\hline $\begin{array}{l}\text { Norepinephrine + Oua- } \\
\text { bain }\end{array}$ & $\begin{array}{c}2 \times 10^{-5} \\
10^{-3}\end{array}$ & 3 & $33.7 \pm 1.7$ & $61.0 \pm 5.4$ \\
\hline
\end{tabular}

'Values are the mean $\mathrm{K}^{+}$release ( \pm S.D.) observed after $10 \mathrm{~min}$ of incubation. Because ouabain was present in the medium in all experiments, these values correspond to the passive efflux of $\mathrm{K}^{+}$. 
of reserpine-treated rats, however, norepinephrine also enhanced the passive efflux of $\mathrm{K}^{+}$to $61 \pm 5 \%$ (Table 3).

The sublingual slices of the treated animals were found to have very high rates of $\mathrm{K}^{+}$uptake. This is shown in Figure 3, which illustrates two types of experiments. In the first type, addition of atropine to the incubation medium 2 min after stimulation with carbamylcholine resulted in a reduction of the $\mathrm{K}^{+}$concentration of the medium (upper panel of Fig. 3). In the second type of experiments, slices of the treated animals incubated in $\mathrm{K}^{+}$-containing medium after a period of preincubation in $\mathrm{K}^{+}$-free medium also showed $\mathrm{K}^{+}$uptake (lower panel, Fig. 3). The extent of active $\mathrm{K}^{+}$uptake observed when the previously stimulated cholinergic receptor was blocked with atropine was similar in slices from control and reserpine treated rats.

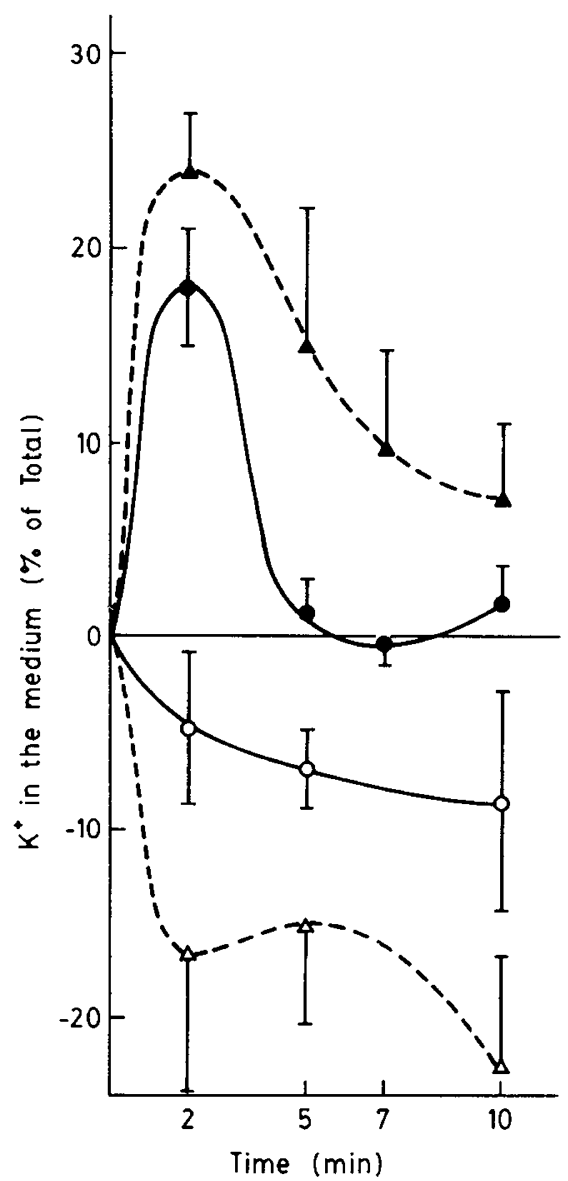

Fig. 3. Upper panel: $\mathrm{K}^{+}$release and uptake from sublingual slices of control (solid line) and reserpine-treated rats (broken line). The slices were stimulated at zero time with carbamylcholine $\left(2 \times 10^{-5} \mathrm{M}\right)$ and at $2 \mathrm{~min}$, atropine $\left(2 \times 10^{-5} \mathrm{M}\right)$ was added to all systems. Vertical bars represent \pm S.E. Number of experiments $=4-5$. Lower panel: $\mathrm{K}^{+}$uptake in sublingual slices of control (solid line) and reserpine-treated rats (broken line). Slices of the two types were preincubated for $15 \mathrm{~min}$ in $\mathrm{K}^{+}$-free Krebs-Ringer bicarbonate medium and then transferred without washing into $\mathrm{K}^{+}$-containing medium. Vertical bars represent \pm S.E. Number of experiments $=3$.

Table 4. In vivo secretory response from the sublingual gland ${ }^{1}$

\begin{tabular}{|c|c|c|}
\hline Type of Animal & $\begin{array}{l}\text { Mean total volume } \\
(\mu \mathrm{l})\end{array}$ & $\begin{array}{l}\text { Mean maximum flow rate } \\
\left(\mathrm{mg} \cdot \mathrm{min}^{-1} \cdot \mathrm{g} \text { wet weight }\right. \\
\end{array}$ \\
\hline & $\begin{array}{c}118 \pm 27 \\
n=41\end{array}$ & $\begin{array}{c}44.9 \pm 3.0 \\
n=41\end{array}$ \\
\hline Reserpine & $\begin{array}{l}53 \pm 4 \\
n=31\end{array}$ & $\begin{array}{c}35.2 \pm 2.4 \\
n=31\end{array}$ \\
\hline
\end{tabular}

${ }^{1}$ Secretion of sublingual saliva was elicited with i.v. infusions of acetylcholine solutions containing $400 \mu \mathrm{g} / \mathrm{ml}$. Infusion rate $=0.052 \mathrm{ml} / \mathrm{min}$.
Saliva secretion in vivo. The autonomic innervation of the sublingual gland is primarily of the parasympathetic type (30) and the gland shows a clear secretory response to parasympathetic, but not to sympathetic, nerve stimulation (37), although high doses of isoproterenol or high frequencies of sympathetic nerve stimulation are capable of eliciting a small secretory response (37). The experiments reported here were confined to the secretory responses to parasympathomimetic stimulation because this is the major pathway for the secretion of both fluid and glycoproteins in this tissue $(10,12,25,37)$.

The total volume of saliva secreted during a 60 -min i.v. infusion of acetylcholine was significantly $(P<0.05)$ reduced in the sublingual glands of reserpine-treated animals (Table 4). The maximum flow rates attained were also reduced, when compared to the values obtained in control glands (Table 4). The excretory patterns for $\mathrm{Na}^{+}$and $\mathrm{K}^{+}$in sublingual saliva of control and reserpine treated rats are shown in Figure 4. The relationship between salivary $\mathrm{Na}^{+}$concentrations and rates of salivary flow in saliva from control animals was similar to that previously reported by Martin and Young (12). Sublingual saliva from reserpinetreated rats did not show significant changes in this relationship, and salivary $\mathrm{Na}^{+}$concentrations fell within the range of those in control saliva at the different rates of flow (Fig. 4). The excretory pattern for $\mathrm{K}^{+}$in saliva from control rats was also similar to those previously reported (12) and did not vary in the saliva for the treated rats (Fig. 4). Salivary $\mathrm{Ca}^{++}$concentrations were found to be uniformly low in the saliva of both control and reserpinetreated rats and no difference was ascertained between the two groups (not shown). The same was true of salivary protein concentrations.

The results of the analysis of the carbohydrate composition of sublingual saliva are shown in Table 5. In general, the total protein-bound carbohydrate and individual carbohydrate components were increased more than $50 \%$ in sublingual saliva of reserpine-treated rats. The generalized increase in salivary concentrations of protein-bound carbohydrates was uniform, so that fucose/sialic acid ratios did not change in the saliva of the treated animals when compared to those in control saliva.

\section{DISCUSSION}

Administration of reserpine to rats for 7 days resulted in an almost 2-fold increase in the number of $\alpha_{1}$-adrenergic receptors and a greater than 3-fold increase in the number of $\beta$-adrenergic receptors in the sublingual gland. Similar changes in adrenergic receptors, although of different magnitude, have been previously observed in the rat submandibular gland $(3,5,6)$. By contrast, the number of muscarinic cholinergic receptors was not significantly increased following reserpine administration.

The changes in $\alpha_{1}$-adrenergic and in cholinergic receptor numbers parallel changes in $\mathrm{K}^{+}$release from gland slices incubated in vitro; thus, addition of carbamylcholine caused a similar extent of net $\mathrm{K}^{+}$release from sublingual slices of control and reserpinetreated rats and the number of cholinergic receptors were also similar in these glands. By contrast, $\alpha_{1}$-adrenergic agonists, which fail to induce $\mathrm{K}^{+}$release in control sublingual slices $(17,28)$ caused a significant net release of $\mathrm{K}^{+}$in the tissue from the treated animals. The increase in the number of $\alpha_{1}$-adrenergic receptors observed after reserpine administration was apparently sufficient to mediate a $\mathrm{K}^{+}$release response to $\alpha_{1}$-agonists and suggests that the depletion of norepinephrine caused by reserpine (2) not only increases the number of receptors but induces a supersensitive response in the sublingual gland. Similar phenomena have been previously described in the submandibular gland of reserpinetreated rats $(6,16)$

The observation that the rat sublingual gland lacks a well defined sympathetic innervation $(30,34)$ is a possible explanation for the presence of moderate numbers of $\alpha_{2}$-receptors in this tissue because denervation increases $\alpha_{2}$-receptor density $(3,4,6)$. As in the submandibular gland (3), chronic reserpine administration was found to increase the number of these receptors in the 

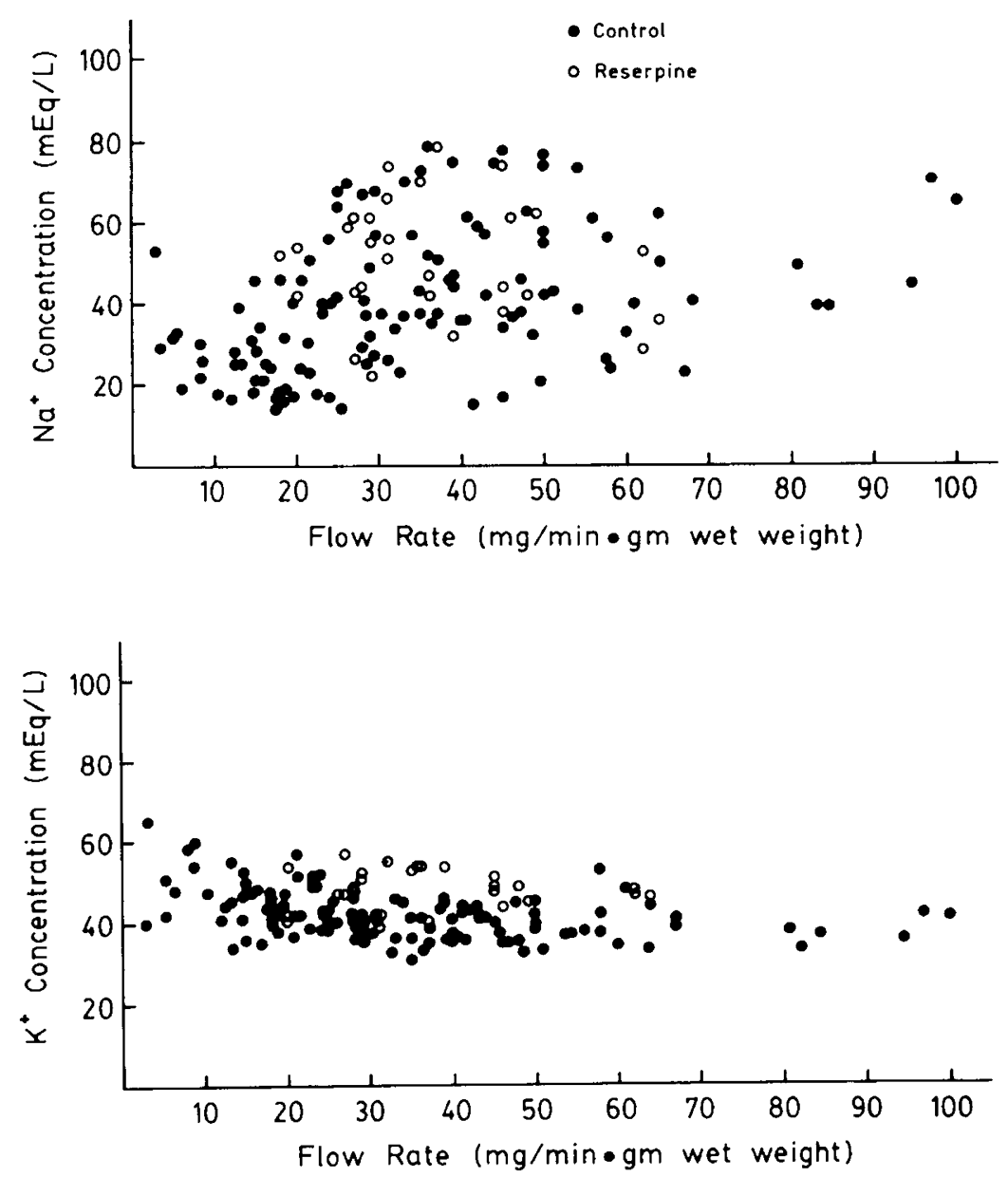

Fig. 4. $\mathrm{Na}^{+}$and $\mathrm{K}^{+}$concentrations of sublingual saliva from control and reserpine-treated rats in relation to the rate of salivary flow. Saliva secretion was stimulated by i.v. infusions of a solution containing $400 \mu \mathrm{g} / \mathrm{ml}$ acetylcholine at a rate of $0.052 \mathrm{ml} / \mathrm{min}$.

Table 5. Protein-bound carbohydrates in acetylcholine-stimulated sublingual saliva ${ }^{1}$

\begin{tabular}{|c|c|c|c|c|c|c|c|}
\hline Type of animal & $n$ & Sialic acid & Fucose & $\begin{array}{c}\mathrm{N} \text {-acetyl } \\
\text { galactosamine }\end{array}$ & $\begin{array}{c}\mathrm{N} \text {-acetyl } \\
\text { glucosamine }\end{array}$ & Galactose & Mannose \\
\hline $\mathrm{C}$ & 20 & $4.68 \pm 0.38$ & $0.23 \pm 0.02$ & $2.31 \pm 0.24$ & $3.26 \pm 0.26$ & $2.68 \pm 0.24$ & $0.50 \pm 0.05$ \\
\hline $\mathbf{R}$ & 18 & $7.19 \pm 0.44$ & $0.35 \pm 0.03$ & $3.54 \pm 0.21$ & $5.01 \pm 0.25$ & $4.15 \pm 0.24$ & $0.77 \pm 0.04$ \\
\hline
\end{tabular}

\footnotetext{
'Values are the means ( \pm S.D. of the mean) of the saliva content of the various carbohydrates listed, expressed as $\mu \mathrm{g} / 10 \mu \mathrm{l}$ of sample.
}

sublingual gland. In the submandibular gland of reserpine-treated rats and in control sublingual glands, stimulation of $\alpha_{2}$-receptors with clonidine failed to cause $\mathrm{K}^{+}$release $(6,17)$. Stimulation of the increased number of $\alpha_{2}$-receptors observed in the sublingual after reserpine administration also failed to enhance $\mathrm{K}^{+}$release over basal (unstimulated) levels. In control sublinguals, however, stimulation of $\alpha_{2}$-receptors with clonidine appears to inhibit cyclic AMP formation (17). The physiologic significance of $\alpha_{2}$-receptors may be related, therefore, to inhibitory effects on cyclic AMP formation. Stimulation of $\beta$-receptors did not cause $\mathrm{K}^{+}$release in the sublingual gland of either control or reserpine-treated rats and exposure to isoproterenol actually inhibited the basal release of $\mathrm{K}^{+}$, as has also been shown in the rat submandibular gland.

As in the case of the submandibular (16), parotid (1), and control sublingual glands (17), the sublingual gland of reserpinetreated rats appeared to release $\mathrm{K}^{+}$through two opposing mechanisms; a passive $\mathrm{K}^{+}$efflux, which occurred upon receptor activation and an active $\mathrm{K}^{+}$reuptake, which depended on the stimulation of an ouabain-sensitive $\mathrm{Na}^{+}, \mathrm{K}^{+}$ATPase. Although the passive $\mathrm{K}^{+}$efflux observed in sublingual slices of reserpine-treated rats in the absence of stimulant or in the presence or carbamylcholine was similar to that seen in control slices, this passive component of the $\mathrm{K}^{+}$release mechanism was found to be en- hanced by norepinephrine in the slices of reserpine treated rats (Table 3). Because this secretagogue also caused an enhanced net release of $\mathrm{K}^{+}$in the slices of the treated animals (Table 2), it seems clear that the $\alpha_{1}$-adrenergic receptors that appeared in increased numbers after reserpine administration (Table 1) are fully functional receptors.

The lack of effect of chronic reserpine administration on muscarinic, cholinergic receptors and on in vitro release of $\mathrm{K}^{+}$in the sublingual gland would suggest that in vivo responses to cholinergic agents may be preserved in the gland of the treated animals. Our results indicate that, as in the case of the two other major salivary glands $(14,31)$, pretreatment with reserpine results in a decreased fluid secretion from the sublingual gland. The mechanisms of fluid secretion in the salivary glands are only partially understood and most likely involve an osmotic transfer of water in response to stimulation-induced ion movements, particularly the active extrusion of $\mathrm{Na}^{+}$. Additional studies are required to elucidate the mechanism by which reserpine administration inhibits fluid secretion in the salivary glands. In contrast to the marked alterations in the electrolyte composition of submandibular saliva induced by chronic reserpine administration $(13,14)$, the electrolytes of sublingual saliva were not modified by the drug treatment. The rat sublingual gland has been shown to secrete saliva by a mechanism 
similar to that of the other salivary glands (12). The mechanism involves the secretion of a primary secretion rich in $\mathrm{Na}^{+}$and poor in $\mathrm{K}^{+}$and its modification by secondary ductal transport processes, involving $\mathrm{Na}^{+}$reabsorption and $\mathrm{K}^{+}$secretion, which render the final saliva hypotonic (12). The reasons for the difference in the effects of chronic reserpine administration on salivary electrolytes of submandibular and sublingual salivas are, therefore, unclear but could be significant in terms of our understanding of differences in the secretory process of mucous and serous glands and of the variability in the composition of the secretory products of these two types of glands which apparently occurs in cystic fibrosis (8). Because chronic reserpine administration altered adrenergic receptors and catecholamine-induced $\mathrm{K}^{+}$release in the sublingual gland, it would be interesting to investigate whether it causes the development of a clear in vivo secretory response to sympathomimetic drugs (which is not present in the normal sublingual), accompanied by abnormalities in saliva composition. The reduction in fluid secretion is likely to modify the physicochemical properties of saliva, particularly if this fluid contains a moderate amount of mucus glycoproteins. The parallel, generalized increase in the salivary content of protein-bound carbohydrates observed in sublingual saliva after chronic reserpine administration may be the first alteration leading to accumulation and precipitation of mucosubstances within the glandular duct system. In general terms, the carbohydrate composition of rat sublingual glycoprotein observed in these studies was similar to that previously reported by Moschera and Pigman (25). A high content of sialic acid and of glucosamine is present in sublingual glycoprotein.

Few studies are available on the sublingual gland of CF patients, but inspissation and leakage of mucus into the interstitium (35) and hyperplasia of mucus acini, without qualitative changes in the character of mucus glycoproteins, have been described (11). No functional studies on sublingual gland or saliva in CF individuals are available and comparisons with the alterations in the gland of the proposed animal model reported here are, therefore, not possible. The alterations reported here support the view that reserpine administration affects mucus-secreting tissues, including the intestine $(9)$, tracheobronchial tree $(18,19)$ and sublingual salivary gland. Such effects are relevant in our attempts to understand the exocrine disturbance in $\mathrm{CF}$ and could help in the elucidation of the disturbance in mucus secretion, which is a primary manifestation of this disease.

\section{REFERENCES AND NOTES}

1. Batzri, S., Selinger, Z., Schramm, M., and Robinovitch, M.: Postassium release mediated by the epinephrine alpha receptor in rat parotid slices. J. Biol. Chem., 248: 361 (1973).

2. Benmiloud, M. and von Euler, U. S.: Effects of bretyllium, reserpine, guanethidine and sympathetic denervation on the noradrenaline content of the rat submaxillary gland. Acta Physiol. Scand., 59: 34 (1963).

3. Bylund, D. B. and Martinez, J. R.: Alpha 2 adrenergic receptors appear in the rat submandibular gland after reserpine administration. Nature, 285: 229 (1980)

4. Bylund, D. B. and Martinez, J. R.: Postsynaptic localization of alpha 2 adrenergic receptors. J. Neurosci., 1: 1003 (1981).

5. Bylund, D. B., Forte, L. R., Morgan, D. W., and Martinez, J. R.: Effects of chronic reserpine administration on beta adrenergic receptors, adenylate cyclase and phosphodiesterase of the rat submandibular gland. J. Pharmacol. Exp. Ther., 218: 134 (1981)

6. Bylund, D. B., Martinez, J. R., and Pierce, D. L.: Regulation of autonomic receptors in rat submandibular gland. Mol. Pharmacol., 21: 27 (1982).

7. Davis, J. N. and Maury, W.: Clonidine and related imidazolines are post-synaptic alpha adrenergic antagonists in dispersed rat parotid cells. J. Pharmacol. Exp. Ther., 207: 425 (1978).

8. di Sant'Agnese, P. A. and Talamo, R. C.: Pathogenesis and pathophysiology of cystic fibrosis of the pancreas. N. Engl. J. Med., 227: 1287, 1343, 1399 (1967)

9. Forstner, J., Maxwell, B. and Roomi, N.: Intestinal secretion of mucus in chronically reserpine treated rats. Am. J. Physiol, 241: G443 (1981).

10. Leeson, C. R.: Structure of salivary glands. In: C. F. Code, Ed.: Handb. Physiol. Section 6, Alimentary Canal, Vol. II Secretion. pp. 463-495 (Amer. Physiol. Soc., Washington, DC, 1967).

11. Lev, R. and Spicer, S. S.: A histochemical comparison of human epithelial mucus in normal and hypersecretory states including pancreatic cystic fibrosis. Am. J. Pathol., 46: 23 (1965).

12. Martin, C. J. and Young, J. A.: Electrolyte concentrations in primary and final

Copyright $(\mathcal{C} 1983$ International Pediatric Research Foundation, Inc

$0031-3998 / 83 / 1707-0523 \$ 02.00 / 0$ saliva of the rat sublingual gland studied by micropuncture and catheterization techniques. Pflugers Arch., 324: 344 (1971).

13. Martinez, J. R., Adshead, P. C., Quissell, D. O., and Barbero, G. J.: The chronically reserpinized rat as a possible model for cystic fibrosis: II Composition and cilioinhibitory effects of saliva. Pediatr. Res., 9: 470 (1975).

14. Martinez, J. R., Quissell, D. O., Wood, D. L., and Giles, M.: Abnormal secretory response to parasympathomimetic and sympathomimetic stimulation from the submaxillary gland of rats treated with reserpine. J. Pharmacol. Exp. Ther., 194: 384 (1975).

15. Martinez, J. R., Adelstein, E., Quissell, D. O., and Barbero, G. J.: The chronically reserpinized rat as a possible model for cystic fibrosis. I Submaxillary gland morphology and ultrastructure. Pediatr. Res., 9: 463 (1975).

16. Martinez, J. R. and Quissell, D.O.: Potassium release from the rat submaxillary gland in vitro: III Effect of pretreatment with reserpine. J. Pharmacol. Exp. Ther., 201: 206 (1977)

17. Martinez, J. R., Bylund, D. B., and Camden, J.: Characterization of autonomic receptors in the rat sublingual gland by biochemical and radioligand assays. Naunyn-Schmiedeberg's Arch. Pharmacol., 318: 313 (1982).

18. Mawhinney, T. P., Feather, M. S., Martinez, J. R., and Barbero, G. J.: The chronically reserpinized rat as an animal model for cystic fibrosis: acute effects of isoproterenol and pilocarpine upon pulmonary lavage fluid. Pediatr. Res., 13: 760 (1979).

19. Mawhinney, T. P., Martinez, J. R., Feather, M. S., and Barbero, G. J.: Composition of pulmonary lavage fluid in control and reserpine treated rats following chronic isoproterenol and pilocarpine administration. Pediatr. Res., 14: 872 (1980).

20. Mawhinney, T. P., Feather, M. S. Martinez, J. R., Garrett, L. S., and Barbero, G. J.: The chronically reserpinized rat as an animal model for cystic fibrosis: effect of parasympathomimetic and sympathomimetic stimulation on the release of isotopically labeled glycoproteins by rat trachea in vitro. CF Club Abstracts, XX Annual Meeting, Atlanta (1979).

21. Mawhinney, T. P., Feather, M. S., Martinez, J. R., and Barbero, G. J.: A rapid, convenient method for the determination of hexosamines as O-acetylated-Omethyloximes by gas-liquid chromatography. Carbohydr. Res., 75: C21 (1979).

22. Mawhinney, T. P., Feather, M. S., Barbero, G. J., and Martinez, J. R.: The rapid, quantitative determination of neutral and amino sugars in glycoproteins by gas-liquid chromatography. Anal. Biochem., 101: 112 (1980).

23. Mawhinney, T. P., Madson, M. A., Rice, R. H., Feather, M. S., and Barbero, G. $\mathrm{J} .:$ Gas-liquid chromatography and mass spectral analysis of per-O-trimethylsilyl acyclic ketoxime neuraminic acid derivatives. Carbohydr. Res., 104:169 (1982).

24. Morton, D., Parker, A., Estrada, P., and Martinez, J. R.: Exocrine pancreatic secretion in rats treated with reserpine following stimulation with pilocarpine, dopamine and caerulein. Pediatr. Res., 14: 18 (1980).

25. Moschera, J. and Pigman, W.: The isolation and characterization of rat sublingual mucus glycoprotein. Carbohydr. Res., 40: 53 (1975).

26. McCurdy, R. E. and Martinez, J. R.: The chronically reserpinized rat as a model for cystic fibrosis: alterations in pancreatic enzyme secretion and storage. Pediatr. Res., 15: 1308 (1981).

27. Perlmutter, J. and Martinez, J. R.: The chronically reserpinized rat as a possible model for cystic fibrosis: VII Alterations in the secretory response to secretin and to cholecystokinin from the pancreas in vivo. Pediatr. Res., 12: 188 (1978).

28. Putney, J. W., Jr., Leslie, B. A., and Marier, S. H.: Calcium and the control of potassium efflux in the sublingual gland. Am. J. Physiol., 235: C128 (1978).

29. Rosenthal, H. E.: Graphic method for the determination and presentation of binding parameters in a complex system. Anal. Biochem., 20: 525 (1967).

30. Scott, B. L. and Pease, D. C.: Electron microscopy of the salivary and lacrimal glands of the rat. Am. J. Anat., 104: 115 (1959).

31. Setser, M. E., Spicer, S. S., Simson, J. A. V., and Martinez, J.R.: Altered granule discharge and amylase secretion in the parotid gland of reserpine treated rats. Lab Invest., 41: 256 (1979).

32. Setser, M. E., Spicer, S. S., Simson, J. A. V., Adamson, M., and Martinez, J. R.: The effects of reserpine on the ultrastructure and secretory responses of the exocrine pancreas. J. Exp. Mol. Pathol., 31: 413 (1979)

33. Simson, J. A. V., Spicer, S. S., Setser, M. E., and Martinez, J. R.: Histochemistry and ultrastructure of rat submandibular acinar cells: effects of chronic reserpine on secretion. Lab Invest., 39: 157 (1978).

34. Snell, R. S. and Garrett, J. R.: The distribution of cholinesterase in the submax illary and sublingual salivary glands of the rat. J. Histochem. Cytochem., 5: 236 (1957).

35. Shackleford, J. M. and Beultey, H. P., Jr.: Carbohydrate histochemistry of the salivary glands and pancreas in cystic fibrosis. J. Histochem. Cytochem., 12: 512 (1963).

36. Svennerholm, V.: Quantitative estimation of sialic acids. Acta Chemica Scand., 12: 547 (1958).

37. Templeton, D. and Thulin, A.: Secretory, motor and vascular effects in the sublingual gland of the rat caused by autonomic nerve stimulation. Q. J. Exp. Physiol., 63: 59 (1978).

38. Whitehouse, M. W.and Zilliken, F.: Isolation and determination of neuraminic (sialic) acids. Meth. Biochem. Anal., 8: 199 (1960)

39. Requests for reprints should be addressed to: Dr. J. Ricardo Martinez, Department of Child Health, University of Missouri School of Medicine, 7th Floor North, Columbia, MO 65212.

40. This study was supported by grant AM18150 from the National Institutes of Health.

41. Received for publication May 4, 1982.

42. Accepted for publication September 20, 1982. 